\title{
Deoxygenation Affects Composition of Membrane-Bound Proteins in Human Erythrocytes
}

\author{
Oksana G. Luneva a Svetlana V. Sidorenko ${ }^{a}$ Olga O. Ponomarchuk ${ }^{a, b}$ \\ Artem M. Tverskoya ${ }^{a}$ Aleksander A. Cherkashin ${ }^{a}$ Oleg V. Rodnenkov ${ }^{c}$ \\ Natalia V. Alekseeva ${ }^{\mathrm{a}} \quad$ Leonid I. Deev $^{\mathrm{a}}$ Georgy V. Maksimov ${ }^{\mathrm{a}} \quad$ Ryszard Grygorczyk $^{\mathrm{b}}$ \\ Sergei N. Orlov a,de \\ aFaculty of Biology, M.V. Lomonosov Moscow State University Moscow, Russia; bUniversity of Montreal \\ Hospital Research Center (CRCHUM) and Department of Medicine, Montreal, Canada; 'Russian \\ Cardiology Research and Production Complex, Moscow, dNational Research Tomsk State University \\ and 'Siberian State Medical University, Tomsk, Russia
}

\section{Key Words}

Erythrocytes $\bullet$ Deoxygenation $•$ ATP release $\cdot$ Hemolysis $\bullet$ Membrane bound proteins

\begin{abstract}
Background/Aims: ATP release from erythrocyte plays a key role in hypoxia-induced elevation of blood flow in systematic circulation. We have previously shown that hemolysis contributes to erythrocyte ATP release triggered by several stimuli, including hypoxia, but the molecular mechanisms of hypoxia-increased membrane fragility remain unknown. Methods: In this study, we compared the action of hypoxia on hemolysis, ATP release and the composition of membrane-bound proteins in human erythrocytes. Results: Twenty minutes incubation of human erythrocytes in the oxygen-free environment increased the content of extracellular hemoglobin by $\sim 1.5$ fold. Paired measurements of hemoglobin and ATP content in the same samples, showed a positive correlation between hemolysis and ATP release. Comparative analysis of SDS-PAGE electrophoresis of erythrocyte ghosts obtained under control and deoxygenated conditions revealed a $\sim 2$-fold elevation of the content of membrane-bound protein with $\mathrm{Mr}$ of $\sim 60 \mathrm{kDa}$. Conclusion: Deoxygenation of human erythrocytes affects composition of membrane-bound proteins. Additional experiments should be performed to identify the molecular origin of $60 \mathrm{kDa}$ protein and its role in the attenuation of erythrocyte integrity and ATP release in hypoxic conditions.

(C) 2016 The Author(s)

Published by S. Karger AG, Basel
\end{abstract}

\section{Introduction}

Regulation of vascular tone facilitates oxygenation and supply of tissues with glucose and other substances required for synthesis of high-energy compounds in order to balance energy consumption. The regulation in lumen diameter of blood vessels in response to 
decline in partial oxygen pressure $\left(\mathrm{pO}_{2}\right)$ is one of the most intriguing and intensively studied phenomena [1]. Dietrich and co-workers were the first to report that the presence of erythrocytes is obligatory for elevation of lumen diameter seen in small vessels isolated from systemic circulation and subjected to hypoxic conditions [2]. Gaseous transmitters (NO, CO, $\mathrm{H}_{2} \mathrm{~S}$ ) and purinergic signaling system are considered among the main tentative mechanisms involving erythrocytes in regulation of blood vessel tone [3]. A key role of purinergic signaling system in regulation of vascular tone under hypoxic conditions is supported by several observations. First, since the seminal paper of Burnstock and Kennedy [4], numerous research teams observed that luminal application of ATP leads to relaxation in different vascular beds (for comprehensive review, see [5, 6]. Second, attenuation of partial oxygen pressure $\left(\mathrm{pO}_{2}\right)$ leads to release ATP from human erythrocytes $[7,8]$ as well as erythrocytes isolated from other mammals studied so far [9]. Third, ATP content in the effluent blood from exercising thigh increased during intense hypoxic exercise as compared to normoxic ones [10]. Several studies demonstrated attenuated ATP release in erythrocytes from older adults [11] and in patients with type 2 diabetes mellitus [12, 13], cystic fibrosis [14] and idiopathic pulmonary hypertension [15] thus suggesting pathophysiological implications of this phenomenon.

In spite of extensive number of observations showing ATP release from erythrocytes subjected to attenuated $\mathrm{pO}_{2}$ as well as other physiological and pathophysiological stimuli including hypercapnia [7], modest acidification [8], elevated temperature [16], deformation [14] and shear stress [17], molecular mechanisms underlying this phenomenon remain poorly understood [3]. Indeed, exocytosis as a major mechanism of hormone and neurotransmitter secretion in nucleated cells should be excluded in mature mammalian erythrocytes lacking endoplasmic reticulum. Keeping this in mind, several non-vesicular mechanisms, including conductive transport via pannexin-1, voltage- and volume-dependent anion channels, and cystic fibrosis transmembrane conductance regulator (CFTR) were proposed to be involved in hypoxia-induced ATP release $[9,18,19]$.

Side-by-side with ATP-conducting pathways listed above, elevation of extracellular ATP concentration may be caused by hemolysis, i.e. disruption of erythrocyte membrane integrity. Indeed, it was shown that intensive hypoxic exercise leads to intravascular hemolysis correlated with elevation of plasma ATP content [20,21]. Recently, we compared ATP and hemoglobin release from human erythrocytes in response to hyposmotic swelling, hypoxia and mechanical stimuli. In these experiments we revealed positive correlation between extracellular content of ATP and hemoglobin [22]. In the case of hypotonic shock, a key role of hemolysis in elevation of extracellular ATP concentration was confirmed by simultaneous luminescence ATP imaging and infrared differential interference contrast images of substrate-attached erythrocytes [22]. It should be noted that Berfeld and Forrester did not find any effect of 50-s hypoxia/hypercapnia on human erythrocyte hemolysis [7]. Negative results were also obtained in comparative analysis of hemoglobin and ATP release evoked by several toxins and activators of cAMP-signaling (for recent review, see [3, 23]). In this study, we performed a correlation analysis of hypoxia-induced ATP and hemoglobin release from human erythrocytes of young volunteers and the action of hypoxia on the composition of membrane-bound proteins as a factor determining erythrocyte integrity.

\section{Matherials and Methods}

\section{Erythrocytes}

Blood samples from young volunteers ( 9 men and 8 women, $26 \pm 4$ and $28 \pm 6$ years old, respectively) were collected in tubes containing heparin $(5 \mathrm{U} / \mathrm{ml})$. Samples were centrifuged $1500 \mathrm{~g}$ for $10 \mathrm{~min}$ at $+4^{\circ} \mathrm{C}$, blood plasma and white blood cells were removed by aspiration and erythrocytes were washed three times in buffer A, containing $145 \mathrm{mM} \mathrm{NaCl}, 5 \mathrm{mM} \mathrm{KCl}, 4 \mathrm{mM} \mathrm{Na}_{2} \mathrm{HPO}_{4}, 1 \mathrm{mM} \mathrm{NaH}_{2} \mathrm{PO}_{4}, 1 \mathrm{mM} \mathrm{MgSO}{ }_{4}, 1 \mathrm{mM} \mathrm{CaCl}_{2}$, $10 \mathrm{mM}$ glucose (pH 7.4). Then, erythrocyte suspension was adjusted to $30 \%$ hematocrit, stored at $+4^{\circ} \mathrm{C}$ and used for experiments within 3 hours.

\section{KARGER}




\section{Cellular Physiology Cell Physiol Biochem 2016;39:81-88

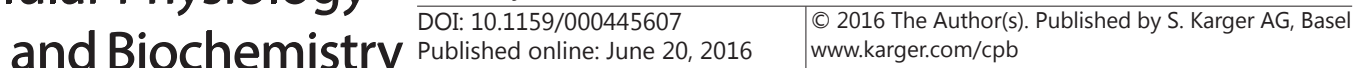 \\ Luneva et al.: Hemolysis and Membrane-Bound Proteins in Deoxygenated Erythrocytes}

Oxygen depletion

Oxygen depletion was performed at room temperature with erythrocyte suspension mixed at $30 \mathrm{rpm}$ in an airtight flow-through chamber with a continuously injected gas mixture containing $\mathrm{N}_{2}$ and $0.04 \% \mathrm{CO}_{2}$. To control oxygen depletion we employed Resonance Raman spectroscopy of hemoglobin with near-infrared laser excitation [24]. Raman spectra were obtained by means of Raman spectrometer utilizing laser $473 \mathrm{~nm}$ (Ciel, Eurolase, Russia) and registration system MORS 1/3648 (Troitsk, Russia) based on CCD TCD1304DG (Toshiba, Japan) with the edge filter LP02-473RS-50 (Shemrock, USA). Considering the laser wavelength and hemoglobin absorption at $473 \mathrm{~nm}$ we worked with non-resonance Raman scattering. Excitation of Raman scattering was done with laser power of $17 \mathrm{~mW}$ per laser spot of $2 \mathrm{~mm}$ in diameter. In preliminary experiments, we observed that in our conditions half-maximal attenuation of the content of oxygenated hemoglobin in erythrocytes occurs in 5-7 min of their exposure to oxygen-free environment. Considering this we extended the incubation time up to $20 \mathrm{~min}$. Figure 1 shows that at this time point oxygen-free gas mixture endorsed complete oxygen depletion of hemoglobin indicated by the absence of $1375 \mathrm{~cm}^{-1} \mathrm{band}$ in the Raman scattering spectra. In the control samples, erythrocyte suspension was injected with air at the same flow intensity. To obtain erythrocyte ghosts, we removed oxygen from the buffer used for erythrocyte lysis and further washout of the erythrocyte ghosts by bubbling it with the $\mathrm{N}_{2} / \mathrm{CO}_{2}$ gas mixture. Oxygen content in the chamber, measured with KE25 oxygen sensor (Figaro, Japan), did not exceed 1\%.

\section{Erythrocyte hemolysis}

Erythrocyte hemolysis was estimated as a percentage of extracellular hemoglobin to the total hemoglobin content in erythrocyte. Degree of hemolysis was estimated by optical density of hemoglobin in supernatant fluid at $415 \mathrm{~nm}$ after sedimentation of erythrocytes at $500 \mathrm{~g}$ for $10 \mathrm{~min}$ at room temperature. The presented values are corrected for the background degree of hemolysis, which was obtained before the experimental treatments.

Extracellular ATP assay

ATP was quantified by a luciferin-luciferase bioluminescence assay. Both extracellular ATP and free hemoglobin were always measured in the same supernatant samples as described in detail elsewhere [22].

\section{Erythrocyte ghosts}

Erythrocyte ghosts were obtained by hypotonic hemolysis in 20 volumes of ice-cold phosphate buffer ( $4.7 \mathrm{mM} \mathrm{Na}_{2} \mathrm{HPO}_{4}, 0.3 \mathrm{mM} \mathrm{NaH}_{2} \mathrm{PO}_{4}, \mathrm{pH}=7.4$ ) followed by three washing and centrifugations at $3500 \mathrm{~g}$ for 40 min at $+4^{\circ} \mathrm{C}$. Then, suspension of erythrocyte ghosts was concentrated by centrifugation in phosphate buffer at $13000 \mathrm{~g}$ for $40 \mathrm{~min}$ at $+4{ }^{\circ} \mathrm{C}$. All procedures required for preparation of erythrocyte ghosts in the media with low oxygen content were performed in the airtight flow-through chamber with a continuous injection of gas mixture, which differed from the air. Erythrocyte ghosts were stored at $-80^{\circ} \mathrm{C}$. Protein concentration was determined by the modified Lowry's method [25] with bovine serum albumin as a standard.

Fig. 1. Raman spectra of erythrocyte suspensions measured after 20-min exposure to air (1) or oxygen-free gas mixture (2).

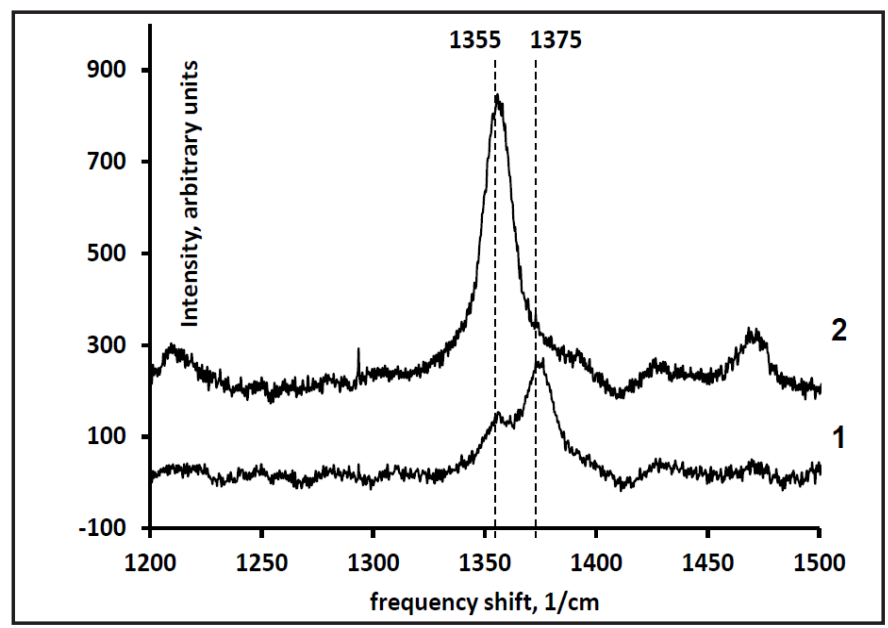




\section{Cellular Physiology Cell Physiol Biochem 2016;39:81-88 \\ and Biochemistry Published online: June 20, $2016 \quad \begin{aligned} & \text { DOI: 10.1159/000445607 } \\ & \begin{array}{l}\text { (c) } 2016 \text { The Author(s). Published by S. Karger AG, Basel } \\ \text { www.karger.com/cpb }\end{array}\end{aligned}$ \\ Luneva et al.: Hemolysis and Membrane-Bound Proteins in Deoxygenated Erythrocytes}

One-dimensional SDS-polyacrylamide gel electrophoresis

One-dimensional SDS-polyacrylamide gel electrophoresis of erythrocyte ghosts was performed in polyacrylamide gel by the Laemmli method [26] using 6\% concentrating gel in $0.5 \mathrm{M}$ Tris- $\mathrm{HCl}$ (pH 6.8), $0.4 \%$ SDS and $10 \%$ separating gel in $1.5 \mathrm{M}$ Tris- $\mathrm{HCl},(\mathrm{pH} 8.8), 0.4 \%$ SDS. The electrophoresis cell was filled with buffer containing $1.92 \mathrm{M}$ glycine, $250 \mathrm{mM}$ tris- $\mathrm{HCl}$ (pH 8.6) and 1\% SDS. The stock of polyacrylamide contained $30 \%$ acrylamide and $0.8 \% \mathrm{~N}, \mathrm{~N}$-methylenebisacrylamide. The protein samples for electrophoresis were prepared in a 4 -fold buffer $(250 \mathrm{mM}$ Tris- $\mathrm{HCl}, \mathrm{pH} 6.8,8 \% \mathrm{SDS}, 40 \%$ sucrose, $0.05 \%$ bromophenol blue, $5 \% \beta$-mercaptoethanol) and incubated for $5 \mathrm{~min}$ at $95^{\circ} \mathrm{C}$. To control protein molecular weight, we loaded molecular weight marker and prepared protein samples in the wells, using a micropipettor with gel loading tips. Electrophoresis was performed in Mini-Protean III cell (Bio-Rad, USA). When the bromophenol blue has run to the bottom of the gel the electrophoresis was terminated by $1 \mathrm{hr}$ incubation at room temperature in solution containing $25 \%$ isopropanol and $10 \%$ acetic acid. Then, proteins on the gel were stained for 1 hr with Coomassie R-250 (0.5\% Coomassie blue R-250. 30\% isopropanol, 10\% acetic acid) and incubated overnight with a solution, containing $25 \%$ ethanol and $7.5 \%$ acetic acid. Then, gel was washed two times in the distilled water. Electrophoregrams were analyzed using One-Dscan software. Protein band densities were normalized to the density of band 3 protein.

Statistical analysis

Statistical analysis was performed using Mann-Whitney U-test in Statistica 8.0 software package.

\section{Results and Discussion}

In the initial experiments, we compared hemoglobin and ATP release in control and deoxygenated erythrocytes isolated from 17 volunteers. Sprague and co-workers reported the negligible hypoxia-induced ATP release in erythrocytes from patients with type 2 diabetes mellitus [12, 13], cystic fibrosis [14] and idiopathic pulmonary hypertension [15]. More recently, Kirby et al. did not detect any actions of low $\mathrm{pO}_{2}$ on ATP release from erythrocytes of aged humans [11]. Considering these data, we limited our correlation analysis of hemolysis and ATP release to young adults. Figures $2 \mathrm{~A}$ and $2 \mathrm{~B}$ show that 20-min hypoxia resulted in elevation of extracellular hemoglobin and ATP content by $\sim 1.4$ and 6-fold, respectively. Importantly, we found a positive correlation between increments of hemolysis and extracellular ATP content evoked by hypoxia with the Pearson product-moment correlation coefficient $r_{x y}=0.8088$ and $p=1.4 \times 10^{-5}$ (Fig. 2C). Our results are consistent with data obtained in human erythrocytes subjected to 30-min low-oxygen conditions [22] but contradict to negative results in human erythrocytes exposed to 50-s hypoxia/hypercapnia [7] and 20-min hypoxia in the presence of 20\% Dextran 40 [21]. It should be underlined that in our experiments hypoxic conditions were applied at room temperature whereas in other studies erythrocytes were incubated at $37^{\circ} \mathrm{C}[7-9,11,15]$. This comment become important because elevation of temperature in the range from 33 to $39^{\circ} \mathrm{C}$ increased baseline ATP release from human erythrocytes by 3 -fold [16]. Considering the methodological differences and experimental protocols of free hemoglobin and ATP determinations, i.e. paired vs. unpaired measurements, additional experiments should be performed to clarify the origin of the divergent results obtained in the cited studies as well as the effect hypoxia on the hemolysis of erythrocytes from persons with above-listed pathologies.

Eryptosis, i.e. the suicidal erythrocyte death characterized by cell shrinkage, membrane blebbing, and phosphatidylserine translocation to the outer membrane leaflet, has been subjected to details investigation by Lang and co-workers [27, 28]. To the best of our knowledge, there is no systematic study on the impact of hemolysis in eryptosis. It should be noted, however, that with a few exceptions [29] eryptosis was not accompanied by any significant accumulation of extracellular hemoglobin. Moreover, both membrane blebbing and phosphatidylserine translocation was detected after 24 hours of the erythrocyte exposure to $\mathrm{Ca}^{2+}{ }_{i}$-rising compounds and other canonical eryptotic stimuli [30-33] contrasting to the rapid hemolysis detected in 20 min of hypoxia (Fig. 2A). 
Fig. 2. Relationship between increments of hemolysis and ATP release in human erythrocytes. Accumulation of extracellular hemoglobin (A) and ATP (B) triggered by 20min incubation of human erythrocytes in normoxic and hypoxic conditions. Means \pm S.E. obtained in 17 experiments with blood from different donors are shown. The total content of hemoglobin and ATP was taken as $100 \%$. * ** $\mathrm{p}<0.02$ and 0.001 compared to normoxia, respectively. Mean values of increments triggered by hypoxia are shown by hutched columns. C. Linear regression analysis of increments of hemolysis and ATP release triggered by hypoxia. $r_{x y}$ is the Pearson product-moment correlation coefficient and $\mathrm{p}$ is the measure of correlation's significance estimated by the Student's t-test.

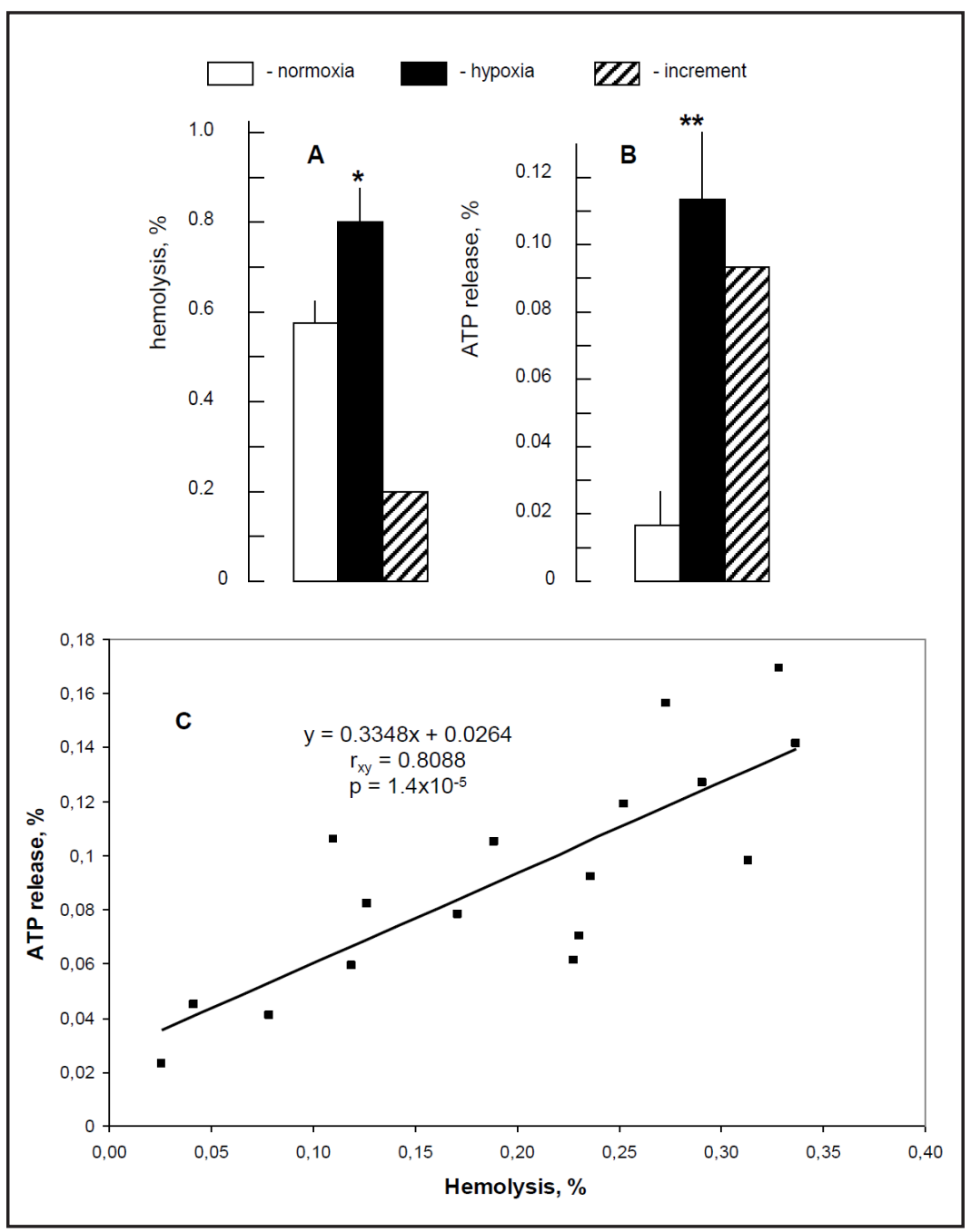

As the only known $\mathrm{O}_{2}$-binding molecules in red blood cells, hemoglobin has been implicated in cellular responses triggered by hypoxia [9]. Indeed, it was shown that skeletal muscle perfusion and plasma ATP in exercising humans exposed to hypoxia, hyperoxia, carbon monoxide inhalation and anemia are closely related to the amount of oxygenated hemoglobin rather than to plasma $\mathrm{pO}_{2}$ and the number of hemoglobin molecules [10,34-36]. Recently Jagger and co-workers demonstrated the negative correlation of ATP release and the content of oxygenated relaxed form of hemoglobin $(\underline{\mathrm{R}}-\mathrm{Hb})$ and suppression of hypoxiainduced ATP release by CO fixing hemoglobin in R-Hb conformation [35]. These data allowed us to propose that deoxygenated tense form of hemoglobin ( $\mathrm{T}-\mathrm{Hb})$ interacts with unknown membrane-bound protein thus triggering downstream signaling cascade terminated by hemolysis and ATP release. To examine the role of membrane-bound proteins in $\mathrm{pO}_{2}$ dependent signaling, we performed comparative analysis of SDS-PAGE electrophoresis of erythrocyte ghosts obtained in control and deoxygenated conditions. Figure 3A shows that 20-min incubation of human erythrocytes in the oxygen-free environment increased the accumulation of hemoglobin in extracellular medium by 1.5 -fold $(\mathrm{p}<0.01)$. We found that in these red blood cells deoxygenation resulted in $\sim 2$-fold elevation of the content of membrane-bound protein with a Mr of $\sim 60 \mathrm{kD}$ and shown as protein X (Fig. 4).

Band 3 protein, i.e. the major integral protein of erythrocytes membrane, plays a key role in the organization of membrane cytoskeleton as well as in anion transport (anion exchanger 1, AE1) [37]. It was shown that both in humans and mice the affinity of band 3 fragment with $\mathrm{M}_{\mathrm{r}}$ of $43 \mathrm{kDa}$ (CDB3) for T-Hb is much higher than for oxygenated hemoglobin [38, 39]. These 
Fig. 3. Effect of hypoxia on hemolysis and the content of membrane bound proteins in human erythrocytes. A - Hemolysis of erythrocytes under conditions of normoxia and hypoxia. Means \pm S.E. from 4 independent experiments are shown. The total content of hemoglobin was taken as $100 \%$. ${ }^{*} \mathrm{p}<0.01$. B - Representative PAGE of erythocyte ghost obtained in normoxic and hypoxic conditions. $\mathrm{C}$ - the relative protein $\mathrm{X}$ content in erythrocyte membranes obtained in control (open bars) and hypoxic (black bars) conditions. Means \pm S.E. from 4 independent experiments are shown. The content of band 3 protein was taken as $100 \%$. $^{*} \mathrm{p}<0.01$.

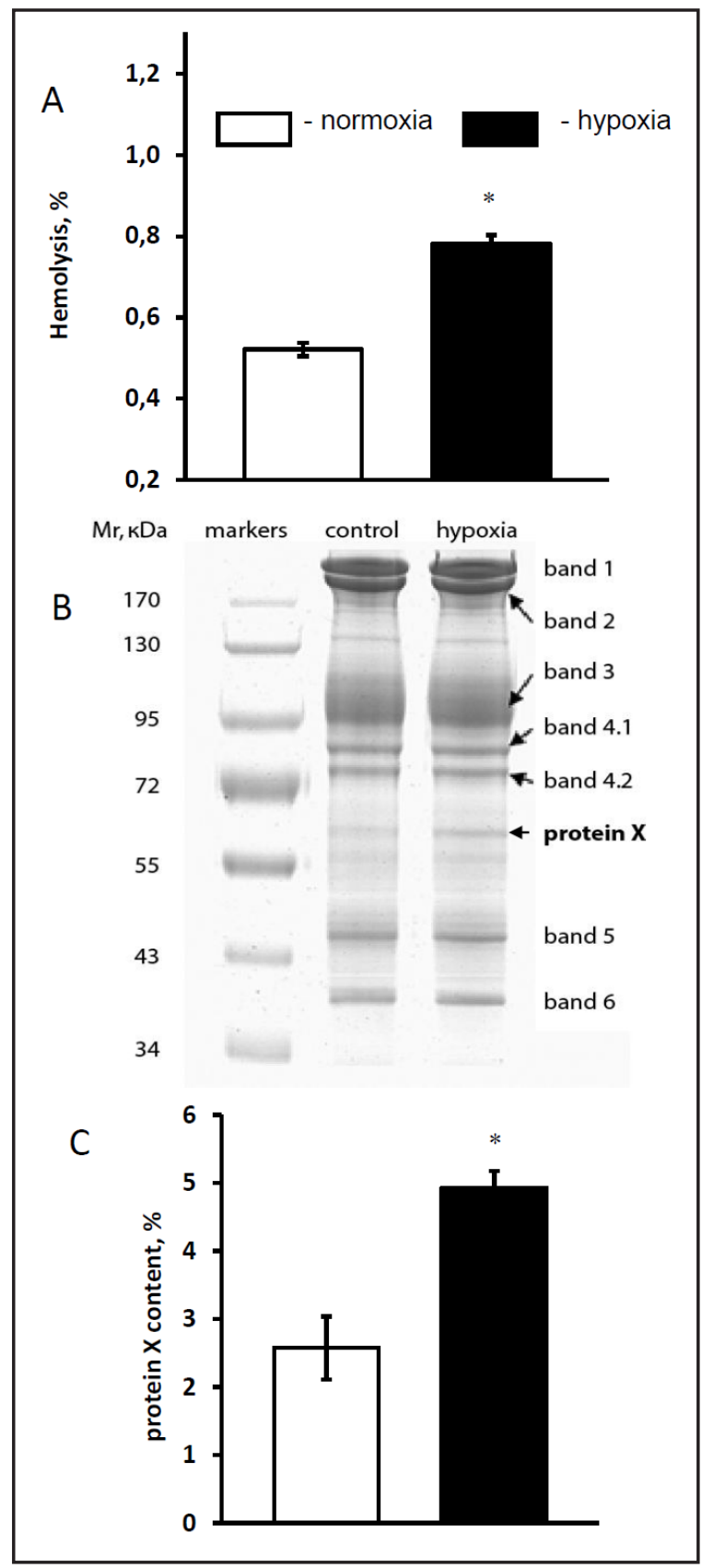

data allowed researcher to assume that $\mathrm{T}-\mathrm{Hb} /$ band3 interaction is crucial for triggering the downstream $\mathrm{pO}_{2}$-dependent signals including altered cytoskeleton assembly which role in the maintenance of erythrocyte membrane integrity is well-documented [40-43]. Indeed, using inside-out vesicles it was shown that addition of T-Hb leads to displacement of ankyrin from band 3 thus weakening membrane-cytoskeleton interactions and promoting plasma membrane vesiculation and rupture [44]. We clear understand, however, that at this stage of knowledge such model is purely speculative. Additional experiments should be performed to identify molecular origin of protein $\mathrm{X}$ and its role in $\mathrm{pO}_{2}$-sensitve, band-3-mediated cytoskeleton network rearrangement, maintenance of plasma membrane integrity and erythrocyte hemolysis in the modest, in vivo-like hypoxic conditions. 


\section{Cellular Physiology Cell Physiol Biochem 2016;39:81-88

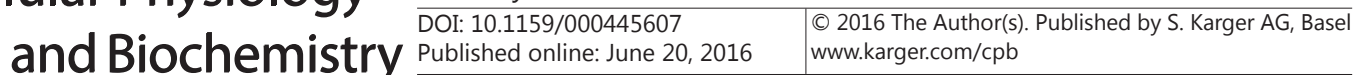 \\ Luneva et al.: Hemolysis and Membrane-Bound Proteins in Deoxygenated Erythrocytes}

\section{Acknowledgements}

This study was supported by grants from the Natural Sciences and Engineering Research Council of Canada, the Russian Foundation for Fundamental Research \#15-04-00101 and grant from the Russian Scientific Foundation \#14-15-00006 and \#16-15-10026.

\section{Disclosure Statement}

All authors have none to declare.

\section{References}

1 Jensen FB: The dual roles of red blood cells in tissue oxygen delivery: oxygen carriers and regulator of local blood flow. J Exp Biol 2009; 212:3387-3393.

2 Dietrich HH, Ellsworth ML, Sprague RS, Dacey RG: Red blood cell regulation of microvascular tone through adenosine triphosphate. Am J Physiol Heart Circ Physiol 2000; 278:H1294-H1298.

3 Luneva OG, Sidorenko SV, Maksimov GV, Grygorczyk R, Orlov SN: Erythrocytes as regulators of blood vessel tone. Biochemistry (Moscow )Supplement Series A: Membrane and Cell Biolgy 2015; 9:161-171.

4 Burnstock G, Kennedy C: A dual function for adenosine 5'-triphosphate in the regulation f vascular tone. Excitatory cotransmitter with noradrenaline from perivascular nerves and locally released inhibitory intravascular agent. Circ Res 1986; 58:319-330.

5 Erlinge D, Burnstock G: P2 receptors in cardiovascular regulation and disease. Purinergic Signal 2008;4:120

$6 \quad$ Ralevic V, Dunn WR: Purinergic transmission in blood vessels. Auton Neurosci 2015;191:48-66.

7 Bergfeld GR, Forrester T: Release of ATP from human erythrocytes in response to brief period of hypoxia and hypercapnia. Cardiovasc Res 1992;26:40-47.

8 Ellsworth ML, Forrester T, Ellis CG, Dietrich HH: The erythrocyte as a regulator of vascular tone. Am J Physiol 1995;269:H2155-H2161.

9 Ellsworth ML, Ellis CG, Goldman D, Stephenson AH, Dietrich HH, Sprague RS: Erythrocytes: oxygen sensors and modulators of vascular tone. Physiology 2008;24:107-116.

10 Gonzalez-Alonso J, Olsen DB, Saltin B: Erythrocyte and regulation of human skeletal muscle blood flow and oxygen delivery. Role of circulating ATP. Circ Res 2002;91:1046-1055.

11 Kirby BS, Crecelius AR, Voyles WF, Dinenno FA: Impaired skeletal muscle blood flow control with advancing age in humans. Attenuated ATP release and local vasodilatation during erythrocyte deoxygenation. Circ Res 2012;111:220-230.

12 Sprague RS, Stephenson AH, Bowles EA, Stumpf MS, Lonigro AJ: Reduced expression of Gi in erythrocytes of humans with diabetes type 2 is associated with impairment of both cAMP generation and ATP release. Diabetes 2006;55:3588-3593.

13 Sprague RS, Goldman D, Bowles EA, Achilleus D, Stephenson AH, Ellis CG, Ellsworth ML Divergent effects of low 02 tension and iloprost on ATP release from erythrocytes of humans with type 2 diabetes: implications for 02 supply to skeletal muscle. Am J Physiol Heart Circ Physiol 2010;299:H566-H573.

14 Sprague RS, Ellsworth ML, Stephenson AH, Kleinhenz ME, Lonigro AJ: Deformation-induced ATP release from red blood cells requires CFTR activity. Am J Physiol Heart Circ Physiol 1998;275:H1726-H1732.

15 Sprague RS, Stephenson AH, Ellsworth ML, Keller C, Lonigro AJ: Impaired release of ATP from red blood cells of humans with primary pulmonary hypertension. Exp Biol Med 2001;226:434-439.

16 Kalsi KK, Gonzalez-Alonso J: Temperature-dependent release of ATP from human erythrocytes: mechanism for the control of local tissue perfusion. Exp Physiol 2012;97:419-432.

17 Wan J, Ristenpart WD, Stone HA: Dynamics of shear-induced ATP release from red blood cells. Proc Natl Acad Sci USA 2008;105:16432-16437.

18 Locovei S, Bao L, Dahl G: Pannexin 1 in erythrocytes: function without a gap. Proc Natl Acad Sci USA 2006;103:7655-7659.

19 Burnstock G: Blood cells: an historical account of the roles of purinergic signalling . Purinergic Signaling 


\section{Cellular Physiology Cell Physiol Biochem 2016;39:81-88 \begin{tabular}{c|l} 
DOI: 10.1159/000445607 & (c) 2016 The Author(s). Published by S. Karger AG, Basel \\
\hline
\end{tabular}

Luneva et al.: Hemolysis and Membrane-Bound Proteins in Deoxygenated Erythrocytes

2015;1:411-434.

20 Shaskey DJ, Green GA: Sports haematology. Sports Med 2000;29:27-38.

21 Mairbaurl H, Ruppe FA, Bartsch P: Role of hemolysis in red cell adenosine triphosphate release in simulated exercise conditions in vitro. Med Sci Sports Exerc 2013;10:1941-1947.

22 Sikora J, Orlov SN, Furuya K, Grygorczyk R: Hemolysis is a primary ATP-release mechanism in human erythrocytes. Blood 2014;124:2150-2157.

23 Sikora J, Orlov SN, Furuya K, Grygorczyk R: Hemolysis is a primary and physiological relevant ATP release mechanism in human erythrocytes. Blood 2015;125:1845-1846.

24 Wood BR, Caspers P, Puppels GJ, Pandiancherri S, McNaughton D: Resonance Raman spectroscopy of red blood cells using near-infrared laser excitation. Anal Bioanal Chem 2007;387:1691-1703.

25 Lowry OH, Rosebrough NJ, Farr AJ, Randall RJ: Protein measurement with the Folin phenol reagent. J Biol Chem 1951;193:265-275.

26 Laemmli UK: Cleavage of structural proteins during the assembly of the head of bacteriophage T4. Nature 1970;227:680-685.

27 Lang F, Qadri SM: Mechanisms and significance of eryptosis, the suicidal death of erythrocytes. Blood Purif 2012;23:125-130.

28 Lang E, Lang F: Mechanisms and pathophysiological significance of eryptosis, the suicidal erythrocyte death. Semin Cell Dev Biol 2015;39:35-45.

29 Voelkl J, Alzoubi K, Mamar A-K, Ahmed MSE, Abed M, Lang F: Stimulation of suicidal eythrocyte death bu increased extracellular phosphate concentrations. Kidney Blood Press Res 2013;38:42-51.

30 Lang KS, Duranton C, Poehlmann H, Myssina S, Bauer C, Lang F, Wieder T, Huber SM: Cation channels trigger apoptotic death of erythrocytes. Cell Death Differ 2003;10:249-256.

31 Schneider J, Nicolay JP, Foller M, Wieder T, Lang F: Suicidal erythrocyte death following cellular K+ loss. Cell Physiol Biochem 2007;20:35-44.

32 Lang F, Gullbins E, Lang PA, Zappulla D, Foller M: Ceramide in suicidal death of erythrocytes. Cell Physiol Biochem 2010;26:21-28.

33 Malik A, Bissinger R, Liu G, Liu G, Lang F: Enhanced eryptosis following gramicidin exposure. Toxins 2015;7:1396-1410.

34 Hanada A, Sander M, Gonzalez-Alonso J: Human skeletal muscle sympathetic nerve activity, heart rate and limb haemodynamic with reduced blood oxygentation and exercise. J Physiol 2001;524:603-615.

35 Jagger JE, Bateman RM, Ellsworth ML, Ellis CG: Role of erythrocyte in regulating local 02 delivery mediated by hemoglobin oxygenation. Am J Physiol Heart Circ Physiol 2015; 280:H2833-22839.

36 Gonzalez-Alonso J, Mortensen SP, Dawson EA, Secher NH, Damsgaard R: Erythrocytes and the regulation of human skeletal muscle blood flow and oxygenation delivery: role of erythrocyte count and oxygenation state of haemoglobin. J Physiol 2006;572:295-305.

37 Low PS, Westfall MA, Allen DP, Appel KC: Characterization of the reversible conformational equilibrium of the cytoplasmic domain of erythrocyte membrane band 3. J Biol Chem 1984;259:13070-13076.

38 Walder JA, Chatterjee R, Steck TL, Low PS, Musso GF, Kaiser ET, Rogers PH, Arnone A: The interaction of hemoglobin with the cytoplasmic domain of band 3 of the human eyrthrocyte membrabe. J Biol Chem 1984;259:10238-10246.

39 Sega MF, Chu H, Christian J, Low PS: Interaction of deoxyhemoglobin with the cytoplasmic domain of murine erythrocyte band 3. Biochemistry 2012;51:3264-3272.

40 Chasis JA, Agre PA, Mohandas N: Decreased membrane mechanical stability and in vivo loss of surface area reflect spectrin deficiencies in hereditry spherocytosis. J Clin Invest 1988;82:617-623.

41 Peters LL, Shivdasani RA, Liu S-C, Hanspal M, John KM, Gonzalez JM, Brugnara C, Gwynn B, Mohandas N, Alper SL, Orkin SH, Lux SE: Anion exchanger 1 (Band 3) is required to prevent erythrocytemembrane surface loss but not to form the membrane skeleton. Cell 1996;86:917-927.

42 Cruz Silva MM, Madeira VMC, Almeida LM, Custodio JBA: Hemolysis of human erythrocytes induced by tamoxifen is related to disruption of membrane structure. Biochim Biophys Acta 2000;1464:49-61.

43 Barvitenko NN, Adragna N, Weber RE: Erythrocyte signal transduction pathways, their oxygenation dependence and functional significance. Cell Physiol Biochem 2005;15:1-18.

44 Stefanovic M, Puchulu-Campanella E, Kodippili G, Low PS: Oxygen regulates the band 3-ankyrin bridge in the human erythrocyte membrane. Biochem J 2013;449:143-150. 